\title{
IN SEARCH OF ASEAN TEACHER EDUCATION QUALITY ASSURANCE MODEL FOR SUSTAINABLE DEVELOPMENT EDUCATION
}

\author{
Wachyu Sundayana, Fuad A. Hamied, and Mohammad Ali
}

\begin{abstract}
Education for Sustainable Development (ESD) is the term mostly used internationally by United Nations. It was first documented in Agenda 21 which identified education as an essential element for attaining sustainable development and underlined areas of action for education. In the United Nations Report (1987) sustainable development is the development that meets the needs of the present without compromising the ability of future generations to meet their own needs. In the context of education, sustainable development refers to the process of providing students with knowledge and understanding, skills and attributes needed to work and live in a way the safeguards environmental, social and economic wellbeing, both in the present and for future generations. The three elements of the ESD are reflected in graduate learning outcomes. In this connection, the articulation and accommodation of the elements of ESD in developing quality assurance system for higher teacher education institutions are considered essential for providing prospective teachers with these elements of higher teacher education standards as they are commonly infused in teacher qualification framework. This framework serves as one of the bases for designing teacher education program or curriculum.
\end{abstract}

\section{KEYWORD:}

ESD teacher education standards, Teacher qualification framework; Teacher education quality assurance

\section{INTRODUCTION}

Teacher Education Institutions in ASEAN are faced with various challenges both internally and externally. Internal and external challenges faced by teacher education institutions in ASEAN, among others include (1) the quality assurance system to guarantee the teacher education institutions that could produce quality teachers; (2) the development of a teacher education qualifications framework that can adopt the competence of future teachers (21 Century Skills);

(3) the existing quality assurance system is too general to accommodate the needs of teacher education institutions, and (3) equivalence and equality graduates within the framework of the ASEAN Economic Community needs in the era of regionalization and globalization.

In response to these challenges, each of the Ministries of Education in ASEAN countries through SEAMEO (Southeast Asian Ministers of Education Organization) has made various efforts, including a study related to the quality assurance systems in the member states (Regional Center for Higher Education and Development/ RIHED 2012. The results of this study became the forerunner to the development of the ASEAN Quality Assurance Framework. Another study related to the quality assurance systems of Asia
Pacific region was the Asia-Pacific Quality Network (APQN) Arrangements on Quality Assurance in Higher Education in the Broader Asia-Pacific Region (Stella \& Department of Education, 2008). The second study was conducted in order to map the quality assurance system of higher education as a generic scope of ASEAN and the Asia Pacific region.

However, a model of quality assurance of higher education which specifically addresses teacher education institutions both at national and ASEAN levels has not been mapped according to the needs fulfillment of qualified teachers in the era of regionalization and globalization.

The assessment model of quality assurance is important, at least to respond to the following issues:

1. The model of teacher education quality assurance as to the provision of professional teachers as needed in both the national and regional contexts;

2. Essential components should be included in teacher education quality assurance system to meet be the needs of teachers in each ASEAN country to be synchronized with the qualification of teachers in a global context that also includes elements of ESD; 
3. The form of institutional quality assurance as to whether to carry out quality assurance of higher education institutions teacher ASEAN credible, accountable and independent?

To respond to the three issues, a study on the model for quality assurance of tertiary or higher teacher education in ASEAN needs to be carried out by faculty members from higher education institutions in the region. Universitas Pendidikan Indonesia (UPI) in collaboration with the University Pendidikan Sultan Idris (UPSI), in consultation with ASEAN Teacher Education Networks (ASTen) took the initiative of the study.

Based on the aforementioned background, this paper is aimed to obtain empirical facts about:

1. The models of existing quality assurance of higher education in ASEAN-related to the implementation of ESD at the schooling system.

2. Essential components of quality assurance system of tertiary teacher education teachers in ASEAN and other regions.

3. Types of quality assurance body in tertiary education institutions which are credible, accountable, and independent.

\section{Conceptual Framework}

\section{Issues on Education for Sustainable Development Implementation}

Education within the perspectives of sustainability basically teaches values as mentioned above. With education, a human can understand themselves and other creatures as well as their relationship with the natural environment and wider social environment. Education teaches the value of appreciating other creatures, the value of understanding diversity and difference as well as justice, responsibility and tries to bring out dialogues on the subjects. That is why education can be an important means to promote the values in order to achieve sustainable development.

The goals for ESD can be articulated with a different way in various places, from local to global scope. Generally there are five global targets to be achieved: (1) to provide an understanding of the importance of education and learning to achieve $\mathrm{SD}$, (2) to form a network, trade and interaction between stakeholders of this program, (3) as a media to promote vision and the transition process towards SD, (4) to improve quality of learning on $\mathrm{SD}$, and (5) to develop strategy to strengthen the capacity of ESD.

Since this constitutes a global awareness, the message is directed to all developed and developing countries. In its implementation, every country must define their own priorities, goals, and action programs which must be adjusted to the local environmental and socio-economic conditions. Furthermore, the resolution of several issues requires international cooperation, such as climate change and biodiversity issues.

Educational reorientation, from primary education to university, which clearly focuses on the development of knowledge, skills, perspectives and norms related to the SD, becomes very important for present and future generations. Reviewing the objectives, contents and teaching method of the existing curriculum is required in order to develop a trans-disciplinary understanding in viewing social, economic and environmental issues.

Awareness of such matters should be introduced since childhood up until adulthood by putting these subjects in the curriculum and syllabus of every school subject. The biodiversity resources, in addition to the natural resources, are also an asset for SD which must be introduced to students through formal or non-formal education.

At higher education level, the level of understanding of SD must also be larger and more complete. Education on ecology or control of waste must be given in every subject and integrated into the general college subject given to all students from all majors. Since it is general and multidisciplinary in nature, the delivery must also be carried out using a simple and popular language. Understanding of waste and pollution (land, water, and air) can be integrated into a particular subject, such as combustion engine subject for students of technical engineering. In addition to explaining the mechanism of car machine, it should also explain the negative impacts of reckless fuel consumption. Hospital waste processing must also be taught to medical and hospital management students. The environmental economy subject is also recommended as one of the subjects that every economy student needs to learn. These are examples of how educational programs for SD must be integrated into university curricula. 


\section{Issues in Tertiary Teacher Education in ASEAN and Asia Countries}

Numerous studies on preservice higher teacher education, such as the comparative study of teacher preparation and qualifications in five nations, namely People's Republic of China, Hongkong, Japan, Republic of Korea, Thailand, and Singapore (Ingersoll, no date) revealed the following issues or problems.

\section{a. Insufficiency of Preservice Teacher Education}

It is widely believed that quality learning in both primary and secondary schools is dependent upon quality teachers. The quality of teacher and teaching is among the most important factors that would shape students' learning and growth. It is widely noted that the impact goes beyond student academic achievement. Experts and observers across the world relate teacher performances to numerous and largest societal goals and problems, such as economic competitiveness and productivity, juvenile delinquency, moral and civic culture, and so on. One of the primary causes of this condition is unqualified teachers which are resulted from the inadequacy of preservice teacher education program. The existing system of teacher preparation programs in tertiary teacher education institutions and government certification standards, all too often lack adequacy.

In this view, teacher preparation programs in tertiary teacher institutions and government certification standards, all too often lack rigor, breadth and depth, resulting in high levels of underqualified teachers and low student performance. Accordingly, the solution, from this viewpoint, lies in making the entry and training requirements for teaching more restrictive, competitive, deeper and more rigorous. Other aspects of tertiary teacher education system must be addressed, such as quality pre-service teacher education and in-service education programs, program management, and quality assurance that covers essential components for producing and maintaining quality teachers.

\section{b. Governace}

The study conducted by Ingersoll et.al (no date) indicated that in almost ASEAN countries, decision-making and governance for the educational system are centralized. In this context, almost all ASEAN Countries adopt a standard- based educational system in which the central government plays a dominant role in developing national education standards. In Indonesia, for instance, a system for all levels of education is based upon standards which are determined by central government. This is stated in Chapter $\mathrm{X}$, Article (3) that curriculum or program for all levels of education is developed on the basis of National Standards of Education (NSE), learners' potentials, potentials of schools and regions where schools or universities are located.

\section{c. Education Requirements}

All of education systems in ASEAN, regardless of their degree of decentralization, requires prospective teachers to complete both educational and professional preparation requirements. In Indonesia, Malaysia, Thailand and Singapore, a four-year bachelor's or undergraduate degree is required for both primary and secondary prospective teachers. The comparison of the systems adopted in the countries can be seen in Table 1.

\section{d. Professional Training Requirements}

Initial Teacher Education (ITE) in ASEAN Countries including People's Republic of China (PRC), South Korea, and Japan consist of two levels, four-year academic education which is equaled to a bachelor degree and one or one and half year professional education. Academic education in ITE provides prospective teachers with the content knowledge, pedagogical content knowledge, general pedagogy, and general education. Whereas, in professional education, ITE institutions provides prospective teachers with pedagogical content knowledge with one or one and half year internship or induction in schools.

Challenges that are encountered by ITE institutions are the alignments of teacher education program components and the nexus of theoretical knowledge and practical knowledge that could be blended through professional education or training. Other challenges are related to the lowest intakes to ITE institutions, infrastructure and facilities for quality learning in ITE institutions, and relevant quality assurance model.

In terms of the approaches to ITE, there are two variants, namely concurrent and consecutive approaches. The former offers and merge professional education and licensing 
Table 1.

Teacher Preparation Requirements by Systems

\begin{tabular}{|c|c|c|c|c|c|c|c|c|}
\hline \multirow{2}{*}{$\begin{array}{l}\text { Country } \\
\text { China }\end{array}$} & \multicolumn{4}{|c|}{ Educational Qualifications } & \multicolumn{4}{|c|}{ Professional Qualificatipns } \\
\hline & $\begin{array}{l}\mathrm{H} \text { i g h } \\
\mathrm{Sch} \text { o o l } \\
\text { Diploma }\end{array}$ & $\begin{array}{l}\text { Associate } \\
\text { or sub- } \\
\text { degree }\end{array}$ & $\begin{array}{l}\text { Bachelor } \\
\text { Degree }\end{array}$ & $\begin{array}{l}\text { Min years } \\
\text { Post Sec- } \\
\text { o n d a r y } \\
\text { Edu }\end{array}$ & $\begin{array}{l}\text { Content } \\
\text { know l- } \\
\text { edge \& } \\
\text { Pedagogy }\end{array}$ & $\begin{array}{l}\text { Certifica- } \\
\text { tion and/ } \\
\text { or License }\end{array}$ & $\begin{array}{l}\text { Test or } \\
\text { Exam }\end{array}$ & $\begin{array}{l}\text { Traning } \\
\text { during } \\
\text { or after } \\
\text { Degree }\end{array}$ \\
\hline Elementary & $\mathrm{x}$ & & & 0 & $\mathrm{x}$ & $\mathrm{x}$ & $\mathrm{x}$ & both \\
\hline L-secondary & & $\mathrm{x}$ & & 2 & $\mathrm{x}$ & $\mathrm{x}$ & $\mathrm{x}$ & both \\
\hline U-secondary & & $\mathrm{x}$ & & 4 & $\mathrm{x}$ & $\mathrm{x}$ & $\mathrm{x}$ & both \\
\hline \multicolumn{9}{|l|}{ Japan } \\
\hline Elementary & & & $\mathrm{x}$ & 4 & $\mathrm{x}$ & $\mathrm{x}$ & - & both \\
\hline Secondary & & & $\mathrm{x}$ & 4 & $\mathrm{x}$ & $\mathrm{x}$ & - & both \\
\hline \multicolumn{9}{|l|}{ Korea } \\
\hline Elementary & & & $\mathrm{x}$ & 4 & $\mathrm{x}$ & $\mathrm{x}$ & - & during \\
\hline Secondary & & & $\mathrm{x}$ & 4 & $\mathrm{x}$ & $\mathrm{x}$ & - & both \\
\hline \multicolumn{9}{|l|}{ Singapore } \\
\hline Elementary & & $\mathrm{x}$ & & 2 & $\mathrm{x}$ & $\mathrm{x}$ & $\mathrm{x}$ & both \\
\hline Secondary & & & $\mathrm{x}$ & $4+1$ & $\mathrm{x}$ & $\mathrm{x}$ & $\mathrm{x}$ & both \\
\hline \multicolumn{9}{|l|}{ Thailand } \\
\hline Elementary & & & $\mathrm{x}$ & $4+1.5$ & $\mathrm{x}$ & $\mathrm{x}$ & $\mathrm{x}$ & both \\
\hline Secondary & & & $\mathrm{x}$ & $4+1.5$ & $\mathrm{x}$ & $\mathrm{x}$ & $\mathrm{x}$ & both \\
\hline \multicolumn{9}{|l|}{ Indonesia } \\
\hline Elementary & & & $\mathrm{x}$ & $4+1$ & $\mathrm{x}$ & $\mathrm{x}$ & $\mathrm{x}$ & both \\
\hline Secondary & & & $\mathrm{x}$ & $4+1$ & $\mathrm{x}$ & $\mathrm{x}$ & $\mathrm{x}$ & both \\
\hline
\end{tabular}

(Source: Engersoll, R.M. et.al ......)

Note: - Test or exam not requored for license, but upon employement

within a bachelor degree program; hence academic education and professional education are completed concurrently. The later separates the two programs, four-year academic education is completed first with the professional education and certification is subsequent.

\section{e. Selectivity of Programs and Attractiveness of Careers}

In countries like Singapore, South Korea, China, and Japan where teachers are ranked relatively high in the existing surveys of occupational prestige, the selectivity of tertiary teacher education is also relatively high when it is compared to other higher education programs. The study in this area indicated that there is always a correlation between teacher's rank within occupational prestige and quality intakes of tertiary education programs. Whereas, in countries where teachers are ranked relatively low in terms of occupational prestige, the selectivity of teacher education program is low.

The comparative study which is conducted by Ingersoll, R.M et al (no date) implied the following points. First, lack of depth, breadth, and rigorous tertiary teacher education and preparation requirements including government licensing and certification standards are possible resources of inadequacies. This can be solved through the reforms of teacher education programs and licensing requirements.

The second possible source of underqualified teachers lies in the failure of teachers to meet the existing requirements and standards. This could include deficits in prospective teachers' ability which is related to both content knowledge and pedagogical content knowledge. This might be caused by incoherent pre-service teacher education. Another factor contributing to unqualified teachers is the inadequacy of the recruitment process.

In line with this, studies which are documented by Zeichner, K. and Conklin,H.G (2008) indicated that features of teacher education programs that could give impact on intended outcomes of teacher education cover among others social and institutional contexts that include institutional type and mission, structure of program, institutional support for teacher education, and policy context, (1) admission process that covers content of 
admissions criteria, program mission, and selectivity of the process; (2) curriculum in course work which cover emphasis on different aspects of preparation, placement within the program of different curricular components, connection to program mission, academic rigor, integration of major topics into the whole curriculum, preparation to teach different subject areas, preparation for teaching students at different age levels, and (3) field experience that include aspects like number, length, and placement of field experiences in the curriculum, and its connection to the rest of the program.

\section{Higher Education Quality Assurance}

Higher Education quality assurance is becoming more prominent in line with the movement of industrialization and standardization in education in the era of regionalization and globalization. Various economic and trade agreements and industry at the regional level, such as Asia-Pacific (APEC) and ASEAN, MEA give impact on higher education (Van Damme, 2002; Mishra, 2007). In this context, the mobility of students, faculty, programs, institutes of higher education rapidly move towards global network (Hou, 2012; Varonism, 2014).This is accompanied by the demand for higher education which continues to increase along with the globalization. It is estimated that by 2025 the projected number of students reached 263 million, an increase of more than 100 million of the data in 2000. (Karaim, 2011). In line with this growth, the need for quality assurance is becoming more prominent. Quality assurance is driving factor for higher education institutions in achieving excellence. Nevertheless, the fulfillment of the quality of programs in higher education institutions that can meet the needs of national and international standards is still a quite a big challenge. (OECD and the World Bank, 2007).

The need of quality assurance in higher education is unavoidable. The following driving factors are identified by some experts (Van Damme, 2002; Mishra, 2007; Harvey, 1998 \& 2005)
a. increased competition following globalization and the Global Agreement on Trade in Services (GATS) b. customer satisfaction and an increasingly
savvy consumer base
c. maintaining standards
d. accountability to stakeholders
e. improving employee morale and satisfaction

f. credibility, prestige and status, and

g. recognition, image, and visibility

\section{Definition of Quality}

Quality could be viewed from different perspectives. According to Garvin (1988) quality can be defined in five groups.

a. Transcendent definitions. These definitions are subjective and personal. They are eternal and go beyond measurement and logical description. They are related to concepts, such as love and beauty which mostly define their meanings based upon our feeling.

b. Product-based definitions. Here quality is seen as a measurable variable. The basis of measurement is objective attributes of the product.

c. User-based definitions. Quality is defined as a means for customer satisfaction. This makes the definitions individual and subjective.

d. Manufacturing-based definitions. Quality is defined as conformance to requirements and specifications.

e. Value-based definition. Quality is defined in relation to costs. Quality is regarded as providing good value for costs.

Based upon those definitions, there are at least two ways to understand the quality. First, quality is perceived as the fulfillment of minimum standards which is defined by experts as contentment of a minimum threshold of the assessed higher education performances (Ashcroft and ForemanPeck, 1994). Second, quality is perceived as the efforts to attain beyond minimum standards as set by the assessed higher education performances. In this connection, Mishra (2007) stated that quality assurance in higher education is associated with the first definition that is moving from fulfilling the threshold to the attainment of the excellence.

Therefore, the quality of higher education is understood as an effort to maintain consistency and efforts to achieve excellence in the delivery of services. In this connection, quality assurance is seen as an approach that can ensure the existence of quality. This type of quality assurance complements procedures and standards which are developed by the higher-education institution to guarantee its educational products. In the context of regionalization and globalization, quality assurance takes place at the internal level of an institution, then it moves to national and regional levels, and even international level. 


\section{Concepts of Tertiary Teacher Education Quality Assurance}

As mentioned above, regionalization and globalization of economy and trade are coupled with the internationalization in higher education sector. The demand for accountability and transparency has fostered quality assurance culture, in addition to challenges confronted by higher educations in the era (Smidt, 2015). Quality assurance is seen as a necessity to comply with the demand for satisfaction in services for the third parties or customers. The fulfillment is related to the services of higher education institution covering their dimensions of input, process, and output. Thus, the perceptions of quality assurance are multidimensional and contextual. Some dimensions of quality of higher education include value, excellence, consistency, and fulfillment of needs and expectations. Not all quality assurance frameworks can meet all aspects of quality. Thus, the selection of quality assurance model becomes essential (Harvey, 2014; Wilger, 1997). The quality assurance framework must be in line with the consistent assessment of the aspects of learning design, content, and pedagogy (Puzziferro \& Shelton, 2008).

According to Barnett (1992), there are three concepts of quality in higher education. The first, the quality should be attached to the value and intellectual property of the academic institutes. This character adheres more to the academic community, than to higher education attainment. The second, the quality is reflected in higher education performance as a product which is completed with its input and output. In this view, the quality of higher education is assessed based on its performance which is derived from achieved performance indicators. Another concept of quality in higher education is perceived from the interaction of lecturers and their students (Lundberg \& Shreiner 2004, Vincent 1987). Therefore, the quality assurance of higher education in general can be clarified in terms of its input, process, and output. A number of experts, including Schindler et al, (2015; Hervey \& Green, 1993) derive quality from the aspects of objectives or outcomes. Meanwhile, a different definition of quality of higher education results from the identification of specific indicators that illustrate the input (lecturers, responsive staffs, and curriculum) and the output (e.g. the rate of graduates enrolled in professional sectors). In terms of process, experts perceive quality assurance from learning interaction between lecturers and students along with a variety of available learning resources.

\section{Models of Higher Education Quality Assurance}

From its historical development side, quality assurance of higher education emerged from the importance of ensuring the quality of the educational program. Quality assurance is a form of educational program evaluation to determine whether its graduates can reach the target which is based on their needs analysis, vision and mission, and potential. As described above, quality assurance of higher education, in a systematic approach that can be observed from three dimensions; input, process, and output. For that reason, some experts, such as Warthen and Sanders (1975; Brown (1995), propose three program evaluation models as references for quality assurance of higher education. Following is the summary of those three models.

According to such experts as Brown, J. D. (1996), and Warthen, B. R. \& Sanders, J. R. (1975), there is at least three approaches in program evaluation: (1) Product-Oriented Approach; (2) Process-Oriented Approach; and (3) DecisionFacilitation Approach.

\section{Product-Oriented Approach}

This approach focuses program evaluation on the achievement of program objectives that is explicitly stated in the educational program. Therefore, this approach requires suggested steps in its implementation. The steps, among others, include the following.

1. Identifying components to be evaluated, namely components of the program.

2. Describing components to be evaluated.

3. Formulating program objectives in in terms of graduate learning outcomes and other program components specifically.

4. Evaluating effectiveness of program, namely achievement of program objectives.

This group is also known as a static approach. This approach is often used in the evaluation of the program in the context of accreditation. Components or elements that are evaluated include, among others, the number of students with unique characteristics, lecturers with academic qualifications and competencies, the ratio of faculty to students, curriculum and learning, facilities and infrastructure supporting activities of learning, lecturers, and students, availability of literature etc. The static approach emphasizes evaluation program to be evaluated based on documentation of components and linkages between components in the curriculum. Evaluation of program by this 
approach is performed by external evaluators or assessors representing accreditation body that could be established either by the government or by professional associations.

\section{Process-Oriented Approach}

This approach does not primarily focus on achieving the program objectives that are explicitly stated in the curriculum. It also focuses on the learning process or the implementation of the program. The evaluation in this approach highlights the connection between the planned program and its implementation, as well as students' learning and achievements reflected from the program implementation. Experts who proposed this approach, among others, were Scriven and Stake.

Scriven introduced two types of program evaluation, namely formative and summative evaluation. Formative evaluation is a program evaluation that focuses on obtaining inputs from program implementation process in order to improve the quality of the learning program. Summative evaluation is a program evaluation that emphasizes on the achievement of program objectives or program effectiveness, efficiency, and success. The information which is collected through this type of evaluation helps to decide whether the program should be continued, improved, or terminated. One example of this approach is one of Stake's models that points out evaluation program phases as follows.

1. Identifying conditions prior to the program implementation; assessing rationale or the foundation of program development.

2. Describing aspects related to program foundation, implementation, and results of the program implementation.

3. Concluding the results of evaluation which is based on the conformity between conditions before and after the program implementation through observation on achieved results; the conclusion is drawn based on standards that are used in a program evaluation.

\section{Policy-making Approach}

This program evaluation approach emphasizes on the function of program evaluation in which policy makers make decisions related to program design, implementation, and results of implementation. One particular model within this approach is developed by Stufflebeam. This model is known as Context (C), Input (I) Process (P), and Product $(\mathrm{P})$ evaluation.
Various studies on quality assurance on both national and regional levels have been growing rapidly. These studies are as follows. Firstly, a research on quality assurance in Pacific Asia was conducted by APQN (Asia Pacific Quality Network). The research results identified three approaches of quality assurance in three areas: accreditation, assessment, and audit. Model of accreditation evaluates whether an institution or a program meets certain specified levels of accreditation. This model emphasizes whether outcomes are met or not by an institution and whether the outcomes affect educational institutions in terms of receiving or obtaining public funding. This accreditation emphasizes more on public accountability. Meanwhile, the assessment approach emphasizes on analyzing outputs. In general, this approach assesses outcomes in stages, both numerical and descriptive. Lastly, the audit approach focuses on the process used by higher education institutions in monitoring academic standards. Meanwhile, Van Damme (2012) argued that there are four models of quality assurance in higher education. The four models are as follows.

The first model is derived from national quality assurance and accreditation systems and agencies and they are strengthened to accommodate international challenges generated by the expansion of transnational education and trade in higher education services. This model is dominant and various developments in quality assurance can be associated with this model.

The model is divided into (1) the strategy of forming mutual cooperation through international cooperation and (2) the strategy of transforming existing quality assurance and accreditation system to accommodate new developments in transnational education services. This strategy opens network and cooperation among quality assurance agencies in the era of regionalization and globalization.

The second model renews networking and exchange towards mutual cooperation, for example in joint cross-border quality assessment projects and formal and informal mutual recognition agreements between agencies. This is followed by agreements on recognition of qualifications or mobility and credit transfer programs.

The third model is a model intended to validate meta-accreditation of quality assurance systems and agencies which are based on a conceptual framework and a set of methodological standards for dependable quality assessment. The metaevaluation can lead to formal recognition or certification of the agency and, eventually, in 
the formal international acceptance of quality assurance or accreditation activities carried out by that agency.

The fourth model is a model that focuses on the development of real international quality assurance and accreditation arrangements.

\section{Quality Assurance Framework for Higher Education}

Referring to a literature review conducted by Owlia and Aspinwall (1996) (cited by Mishra 2007) on quality assurance, the dimensions in quality assurance of higher education can be grouped into aspects as listed in Table 2 below.

\section{Table 2.}

Dimensions of Quality Assurance of Higher Education

\begin{tabular}{|l|l|}
\hline \multicolumn{1}{|c|}{ Dimensions } & \multicolumn{1}{|c|}{ Characteristics } \\
\hline Tangibles & $\begin{array}{l}\text { Sufficient equipment/facilities, } \\
\text { Modern equipment/facilities, } \\
\text { Ease of access, Visually appeal- } \\
\text { ing environment, Support servic- } \\
\text { es (accommodation, sports...) }\end{array}$ \\
\hline Competence & $\begin{array}{l}\text { Sufficient (academic) staff, } \\
\text { Theoretical knowledge, quali- } \\
\text { fications, Up-to-date Practical } \\
\text { knowledge, Teaching expertise, } \\
\text { and communication. }\end{array}$ \\
\hline Attitude & $\begin{array}{l}\text { Understanding students' needs, } \\
\text { Willingness to help, Availability } \\
\text { in academic supervision, Giv- } \\
\text { ing personal attention, Giving } \\
\text { Emotional support, and Giving } \\
\text { Empathy. }\end{array}$ \\
\hline Content & $\begin{array}{l}\text { The relevance of curriculum } \\
\text { to students' future career, Ef- } \\
\text { fectiveness, Containing primary } \\
\text { knowledge/skills, Availability } \\
\text { of computers, Communication } \\
\text { skills and team working, Flex- } \\
\text { ibility of knowledge, Containing } \\
\text { cross-disciplinary. }\end{array}$ \\
\hline $\begin{array}{l}\text { Effective presentation, Effec- } \\
\text { tive Sequencing, Consistency } \\
\text { in providing Fair examinations, } \\
\text { Feedback from students, and } \\
\text { Encouraging students. }\end{array}$ \\
\hline $\begin{array}{l}\text { Trustworthiness, Giving a valid } \\
\text { reward, Keeping promises, Ob- } \\
\text { taining goals, Handling com- } \\
\text { plaints, and solving problems. }\end{array}$ \\
\hline
\end{tabular}

\section{Teacher Education Standards}

Based on the model of teacher education and principles of teacher education and dimensions in quality assurance in higher education, teacher education standards should include the following. (Source: Adapted from The National Council for Accreditation of Teacher Education).

\section{Standard 1: Framework of teacher qualifications or competence}

Teacher qualifications framework must portray a map of teacher competence in accordance with demands of all stakeholders. The qualification framework should cover aspects of knowledge, skills, attitudes, and behavior of prospective teachers. In the context of ESD, formulation of graduate qualifications of higher teacher education must include the elements of ESD, namely knowledge and understanding, skills and attributes needed to work and live in a way the safeguards environmental, social and economic wellbeing, both in the present and for future generations. The elements must be formulated in alignment with the characteristics of the field of study or subject matter in the forms of validated indicators.

\section{Standard 2: Evaluation and Assessment System}

The unit that is evaluated must possess an assessment and evaluation system that can guarantee the mapping of graduates' competence.

\section{Standard 3: Field and Internships}

The unit that is evaluated must possess standard operation procedure for field practices and internships in partner or laboratory schools.

\section{Standard 4: Diversity}

The evaluated program in the unit must possess curriculum design, implementation, and evaluation that enable graduates to receive various knowledge and experiences and as result, develop graduates' capabilities required in their profession.

\section{Standard 5: Teacher Qualifications, Performance, and Development}

The teaching staff in the unit that is evaluated must possess qualifications, performance, and professional development on an ongoing basis to produce qualified graduates.

Standard 6: Unit of Governance and Availability of Supporting Facilities and Infrastructure in teacher education.

The unit that is evaluated must have leadership, authority, budget, personnel, facilities, and resources. It also includes ICT systems ensuring the readiness of professional teacher according to the demands of stakeholders. The development stages of the quality-based standards are as follows. 
Table 3.

Development Stages of Quality Assurance Standards

\begin{tabular}{|c|c|c|c|}
\hline Stages & Parties & Products & $\begin{array}{l}\text { Implemen- } \\
\text { tation Time }\end{array}$ \\
\hline $\begin{array}{l}\text { 1. Needs Assessment of ASEAN } \\
\text { Qualification Framework for Teacher } \\
\text { Education and QA Framework }\end{array}$ & $\begin{array}{l}\text { Team of experts and } \\
\text { policy makers in the im- } \\
\text { plementation of ASEAN } \\
\text { teacher education }\end{array}$ & $\begin{array}{l}\text { Information in the form } \\
\text { of input for ASEAN } \\
\text { Qualification Frameworks } \\
\text { for Teacher Education }\end{array}$ & Jan 2017 \\
\hline $\begin{array}{l}\text { 2. Review of Paper of ASEAN Quali- } \\
\text { fication Framework for Teacher Edu- } \\
\text { cation and QA framework based on } \\
\text { input from the needs assessment }\end{array}$ & $\begin{array}{l}\text { Appointed team and } \\
\text { related experts }\end{array}$ & $\begin{array}{l}\text { Early Draft of ASEAN } \\
\text { Qualification Frameworks } \\
\text { for Teacher Education }\end{array}$ & $\begin{array}{l}\text { March-April } \\
2017\end{array}$ \\
\hline $\begin{array}{l}\text { 3. Review of Draft of ASEAN Quali- } \\
\text { fication Framework for Teacher Edu- } \\
\text { cation and QA framework }\end{array}$ & $\begin{array}{l}\text { Panel of Experts through } \\
\text { FGD }\end{array}$ & $\begin{array}{l}\text { Draft of ASEAN Quali- } \\
\text { fication Frameworks for } \\
\text { Teacher Education }\end{array}$ & May 2017 \\
\hline $\begin{array}{l}\text { 4. Limited trial of the ASEAN Quali- } \\
\text { fication Framework for Teacher Edu- } \\
\text { cation and QA framework }\end{array}$ & $\begin{array}{l}\text { Stakeholders within the } \\
\text { ASEAN Teacher Educa- } \\
\text { tion Institutions }\end{array}$ & $\begin{array}{l}\text { Checklist problems to } \\
\text { enter a revised draft of } \\
\text { ASEAN Qualification } \\
\text { Frameworks for Teacher } \\
\text { Education }\end{array}$ & $\begin{array}{l}\text { June-July } \\
2017\end{array}$ \\
\hline $\begin{array}{l}\text { 5. Final draft of ASEAN Qualification } \\
\text { Framework for Teacher Education and } \\
\text { QA framework }\end{array}$ & Team of developers & Final draft & August 2017 \\
\hline $\begin{array}{l}\text { 6. Determining the Scope, Approach, } \\
\text { Instrument, and Quality Assurance } \\
\text { Agency for ASEAN Teacher Educa- } \\
\text { tion }\end{array}$ & $\begin{array}{l}\text { Team of developers } \\
\text { from UPI and UPSI }\end{array}$ & $\begin{array}{l}\text { Early Draft of ASEAN } \\
\text { Qualification Frameworks } \\
\text { for Teacher Education }\end{array}$ & $\begin{array}{l}\text { September } \\
2017\end{array}$ \\
\hline $\begin{array}{l}\text { 7. Validation of Component draft } \\
\text { and Quality Assurance Instrument of } \\
\text { ASEAN Teacher Education }\end{array}$ & $\begin{array}{l}\text { Team of developers } \\
\text { from UPI and UPSI }\end{array}$ & $\begin{array}{l}\text { Early draft of Component } \\
\text { and Quality Assurance } \\
\text { Instrument of ASEAN } \\
\text { Teacher Education }\end{array}$ & $\begin{array}{l}\text { Sept-Oct } \\
2017\end{array}$ \\
\hline $\begin{array}{l}\text { 8. Validation of Component draft } \\
\text { and Quality Assurance Instrument of } \\
\text { ASEAN Teacher Education }\end{array}$ & $\begin{array}{l}\text { Team of developers } \\
\text { from UPI and UPSI; } \\
\text { and Stakeholders of the } \\
\text { ASEAN Teacher Educa- } \\
\text { tion }\end{array}$ & $\begin{array}{l}\text { Revision of Component } \\
\text { and Quality Assurance } \\
\text { Instrument of ASEAN } \\
\text { Teacher Education }\end{array}$ & $\begin{array}{l}\text { Nov-Des } \\
2017\end{array}$ \\
\hline $\begin{array}{l}\text { 9. Socialization of Quality Assurance } \\
\text { of ASEAN Teacher Education }\end{array}$ & $\begin{array}{l}\text { ASEAN Teacher Educa- } \\
\text { tion Institutions }\end{array}$ & $\begin{array}{l}\text { Quality Assurance of } \\
\text { ASEAN Teacher Educa- } \\
\text { tion has been socialized }\end{array}$ & Jan 2018 \\
\hline $\begin{array}{l}\text { 10. Determining the Cooperation and } \\
\text { Agreement for the Implementation } \\
\text { of Quality Assurance of ASEAN } \\
\text { Teacher Education }\end{array}$ & $\begin{array}{l}\text { ASEAN Teacher Educa- } \\
\text { tion Institutions }\end{array}$ & $\begin{array}{l}\text { Quality Assurance Agency } \\
\text { of ASEAN Teacher Edu- } \\
\text { cation }\end{array}$ & March 2018 \\
\hline
\end{tabular}

\section{REFERENCES}

Ashcroft, K. \& Foreman-Peck, L. 1996. Managing Teaching and Learning in Further and Higher Education. London: Falmer Press.

Adote-Bah Adotevi, J. n.d. . Developing Teacher Qualifications Frameworks. Dkar; Unesco.

Brown, J. D. 1995. The Elements of Language Curriculum; A systematic Approach to Program Development. Boston, Mass.: Heinly \& Heinle Publishers.

Garvin, D. A. 1988. Managing Quality: The Strategic and Competitive Edge. Cambridge, Mass: Harvard Business School.
Green, D. (1993). Defining quality. Assessment and Evaluation in Higher Education, 18(1), 9-34.

Harvey, L. (1995), "Quality Assurance Systems, TQM and the New Collegialism", Centre for Research into Quality, University of Central England, Birmingham, UK.

Harvey, L. , (1998) An assessment of past and current approaches to quality in higher education, Australian Journal of Education, Vol. 42, No. 3, November.

Hou, A. (2012). Mutual recognition of quality assurance decisions on higher education institutions in three 
regions: A lesson for Asia. Higher Education, 64(6), 911-926. http://dx. doi. org/10. 1007/s10734012-9536-1

Harvey, L. , \& Knight, P. T. (1993). Transforming higher education. Buckingham, England: Society for Research in Higher Education \& Open University Press.

Harvey, L. , \& Knight, J. (2005). International race for accreditation stars in cross-border education. International Higher Education, 40, 2-3.

Ingersoll, R.M. Ed. (tanpa tahun). A Comparative Study of Teacher Preparation and Qualifications in Six Nations. U.S. Department of Education:Consortium for Policy Research in Education (CPRE)

Karaim, R. (2011). Expanding higher education. CQ Global Researcher, 5, 525-572. Available: http://library. cqpress. com/

Mishra, D. S. (2007). Quality Assurance in Higher Education: An Introduction - Revised Edition. Bangalore: National Assessment and Accreditation Council, India.

Nicholson, K. 2011. Quality Assurance in Higher Education: A Review of the Literature. Canada: Council of Ontario Universities Degree Level Expectations Project McMaster University Ontario.

Ryan, T. 2015. Quality Assurance in Higher Education: A Review of Literature. Available: www. hircjournal. com

Scriven, M. 1973. The Methodology of Evaluation. In B. R. Woerthen \& J. R. Sanders, Evaluation in Education; Theory and Practice. Belmont, CA: Wadsworth

Stufflebeam, D. L. (1974). Alternative Approaches to educational evaluation. In W. J. Popham
(Ed. ), Evaluation in Education: Current application. Berkley, C,A.: McCutchan.

SEAMEO REIHED. 2012. A Study on Quality Assurance Models in Southest Asian Countries, Towards Southeast Asian Quality Assurance Framework. Bangkok, Thailand: SEAMEO REIHED.

Srikanthan, G. n. d. . Developing Model for Quality in Higher Education. Bundoora, Victoria 3083, Australia: Centre for Management Quality Research

Smidt, H. 2015. European quality assurance-A European higher education area success story [overview paper]. In A. Curaj, L. Matei, R. Pricopie, J. Salmi, \& P. Scott (Eds. ), The European higher education area: Between critical reflections and future policies (pp. 625-637). London, UK: Springer Open. http://dx. doi. org/10. 1007/978-3-31920877-0_40

Van Damme, Dirk. 2002. Trends and Models In International Quality Assurance and Accreditation in Higher Education in Relation to Trade in Education Services. Washington DC: USA. OECD Forum.

Varonism, E. M. (2014). Most courses are not born digital: An overview of the Quality Matters peer review process for online course design. CampusWide Information Systems, 31(4), 217-229. http://dx. doi. org/10. 1108/CWIS-092013-0053

Woerthen, B. R. \& J. R. Sanders. 1973. Evaluation in Education; Theory and Practice. Belmont, CA: Wadsworth 